\title{
Effects of Management Practices on Soil Properties and Plant Nutrition in Hay Meadows in Picos de Europa
}

\author{
Judith Álvarez $^{1, *}$, Elías Afif ${ }^{1}$, Tomás E. Díaz ${ }^{2}$, Laura García ${ }^{3}$ and Jose A. Oliveira ${ }^{4}$ (D) \\ 1 Agroforestry Engineering Area, Department of Organisms and Systems Biology, Polytechnic School of Mieres, \\ University of Oviedo, 33600 Mieres, Asturias, Spain; elias@uniovi.es \\ 2 Botanical Area, Department of Organisms and Systems Biology, Faculty of Biology, University of Oviedo, \\ 33071 Oviedo, Asturias, Spain; tediaz@uniovi.es \\ 3 Institute of Natural Resources and Territorial Planning, University of Oviedo, 33600 Mieres, Asturias, Spain; \\ laura.indurot@uniovi.es \\ 4 Plant Production Area, Department of Organisms and Systems Biology, Polytechnic School of Mieres, \\ University of Oviedo, 33600 Mieres, Asturias, Spain; oliveira@uniovi.es \\ * Correspondence: UO81490@uniovi.ES; Tel.: +34-687-831-289
}

check for

updates

Citation: Álvarez, J.; Afif, E.; Díaz, T.E.; García, L.; Oliveira, J.A. Effects of Management Practices on Soil

Properties and Plant Nutrition in Hay

Meadows in Picos de Europa.

Environments 2021, 8, 38.

https://doi.org/10.3390/

environments 8050038

Academic Editor:

Christopher Bryant

Received: 24 January 2021

Accepted: 23 April 2021

Published: 25 April 2021

Publisher's Note: MDPI stays neutral with regard to jurisdictional claims in published maps and institutional affiliations.

Copyright: (c) 2021 by the authors. Licensee MDPI, Basel, Switzerland. This article is an open access article distributed under the terms and conditions of the Creative Commons Attribution (CC BY) license (https:/ / creativecommons.org/licenses/by/ $4.0 /)$.

\begin{abstract}
Fertilization and mowing affects the physico-chemical properties of soils, as well as the characteristics of the plants growing on them. Changes in the management techniques are causing semi-natural grasslands to disappear all over Europe. These grasslands host a great amount of diversity, thus their conservation is a top priority. This work studies whether the kind of management has an influence on the soil properties and the foliar content in macronutrients in 25 hay meadows located in Picos de Europa (10 in Asturias, 10 in Castilla y León and 5 in Cantabria). Soils at a 0-20 cm depth showed a high content of organic matter and a low $\mathrm{C} / \mathrm{N}$ ratio. Effective cation exchange capacity was adequate for a texture, which varied from sandy clay loam to loam, with an average clay content of $17 \%$. Mean values of foliar nutrient concentrations showed a deficiency in $\mathrm{K}$. In this study, management practices were shown to affect some properties of the soils, namely $\mathrm{pH}$, sand percentage and exchangeable $\mathrm{K}$ and $\mathrm{Ca}$, to different extents. The highest values of $\mathrm{pH}$ and exchangeable $\mathrm{Ca}$ were significantly correlated with the least intensive management.
\end{abstract}

Keywords: grasses; legumes; meadows management; plant analyses; soil characteristics

\section{Introduction}

Hay meadows have been included in Habitat Directive 92/43 EEC (EnvironmentEuropean Commission) as Habitat 6510 (Low-Land meadows, alliance Arrhenatherion [1]) and Habitat 6520 (Mountain meadows, alliance Triseto-Polygonion bistortae [2]) because of their high plant and animal diversity [3]. These ecosystems are suffering regression everywhere in Europe due to changes in management practices [4]. Traditional management of hay meadows is only retained in Romania, Bulgaria, North-western Portugal, Northern Spain and Pyrenees [5]. The biggest threats to hay meadows are the intensification of management, where the topography allows for it, and abandonment of areas that are difficult to access. To obtain the high yields that are characteristic of intensive systems, the use of fertilizers is necessary. This creates an environment in which only some productive species survive (very competitive species that respond to nutrient supply growing rapidly and outcompeting other species), the landscape changes and strategical habitats are destroyed. This degenerative process leads to diversity loss [4], which also happens in other natural agricultural contexts, such as those related to pasture management [6] or to in situ conservation as hay meadows are environments rich in crop wild relatives and/or endangered species [6,7]. However, abandonment reduces the frequency of the perturbation, which greatly favors the herbaceous species, and in the mid and long term leads to communities richer in ligneous species, which are generally less diverse [8]. Hay 
meadows play an important role in the production of milk and meat and for this reason it is important to determine the contents of nutrients in semi-natural meadows $[9,10]$.

Land use changes affect vegetation composition, structure and processes, as well as soil physics and chemistry [11]. Organic matter, total nitrogen and $\mathrm{pH}$ show lower values in cultivated and grazing land than in forests and the opposite is true for phosphorus [12,13]. Grassland management usually includes grazing, mowing and fertilization. Grazing has remarkable effects on soil physical properties (soil porosity, bulk density, etc.) primarily by trampling, whose effects depend heavily on animal type and grazing intensity [14]. Livestock also affects soil biochemical properties, such as $\mathrm{pH}$, soil organic matter and total $\mathrm{N}$, through excreta deposition and defoliation [14]. Mowing may have an effect on soil physical properties due to degradation of soil structure and a decrease of soil organic matter by plant biomass removal. However, an intermediate mowing intensity is favorable and can be integrated into grassland management without deteriorating soil physical properties if meadows are managed for conservation purposes [14]. There are also several examples of effects on soil chemical properties produced by long-term mowing, such as nutrient content and plant uptake increase [14].

Studies on fertilization have sometimes produced contradictory results, which may respond to differences in yields, plant litter quality and soil aggregation [14]. Messiga et al. [15] found that phosphorus in the soil was increased by the application of $\mathrm{P}$ fertilizers, and soil $\mathrm{pH}$ was decreased by $\mathrm{N}$ application, which also affected the availability of exchangeable cations, while total carbon was not affected by either $\mathrm{N}$ or $\mathrm{P}$ fertilization. In a long-term experiment in a wet grassland under different NPK fertilization treatments [16], the results showed that land use was more important in soil acidification than fertilizers themselves. According to the same study, organic soil carbon and available $\mathrm{K}$ fluctuated substantially according to fertilizer rates, while total nitrogen, $\mathrm{C}: \mathrm{N}$ ratio and available $\mathrm{P}$ showed less dramatic changes. In another experiment, after 45 years of fertilization there were significant effects on the concentrations of plant-available $\mathrm{P}, \mathrm{K}$ and $\mathrm{Ca}$, but none on organic $\mathrm{C}$, soil total $\mathrm{N}$ or $\mathrm{C}: \mathrm{N}$ ratio [17]. However, differences between different PK or NPK fertilization treatments were small. In Northern Europe, the intensive use of fertilizers during the second half of the 20th century gave the origin great P surpluses, which led to the introduction of measures to control P losses [18]. The effects of $\mathrm{N}$ fertilizers, even in large quantities, disappear within ten years since the last application, whereas the effects of P fertilizers last for more than 25 years after the last addition [19].

The European project Interreg SUDOE "SOS PRADERAS" SOE1/P5/E0376 aims at trying to avoid the disappearance of human-managed hay meadows and their associated biodiversity by promoting the sustainable management of these habitats in the areas of the Territorial Cooperation Programme for South Western Europe (SUDOE).

This work, framed within the "SOS PRADERAS" project, focuses on the National Park of Picos de Europa, North of Spain, which spreads across the Autonomous Communities of Asturias, Castilla y León and Cantabria. The main goal of the study was to evaluate the edaphic features and nutritional status of the plant biomass of hay meadows in 25 plots in this National Park. Meadows were compared to the aim of determining if different types of management have different effects on soil properties and on foliar nutrient concentrations. For this purpose, meadows were arranged in four groups according to the use of fertilizers and the use of a tractor for mowing.

\section{Materials and Methods}

Picos de Europa is an Atlantic mountain chain located north of the Cantabrian range (Figure 1A). It was the first National Park declared in Spain in 1981. Its exceptional landscape relies on the glacial, fluvial and karstic carving in a high mountain environment under an Atlantic climate [20]. From a geological point of view, limestone is dominant in the massifs; in the Valdeón valley and the high part of Liébana and Sajambre siliciclastic, materials are abundant (sandstone, slate and conglomerates), whereas in the low part of Sajambre, carbonate and siliciclastic materials coexist. Picos de Europa represents the 
greatest limestone formation of the Atlantic Europe, with chasms reaching up to $1000 \mathrm{~m}$ deep and lakes and erosion from a glacial origin [21]. Soils in Picos de Europa have been classified as Cryorthents and Eutrochrepts [22].
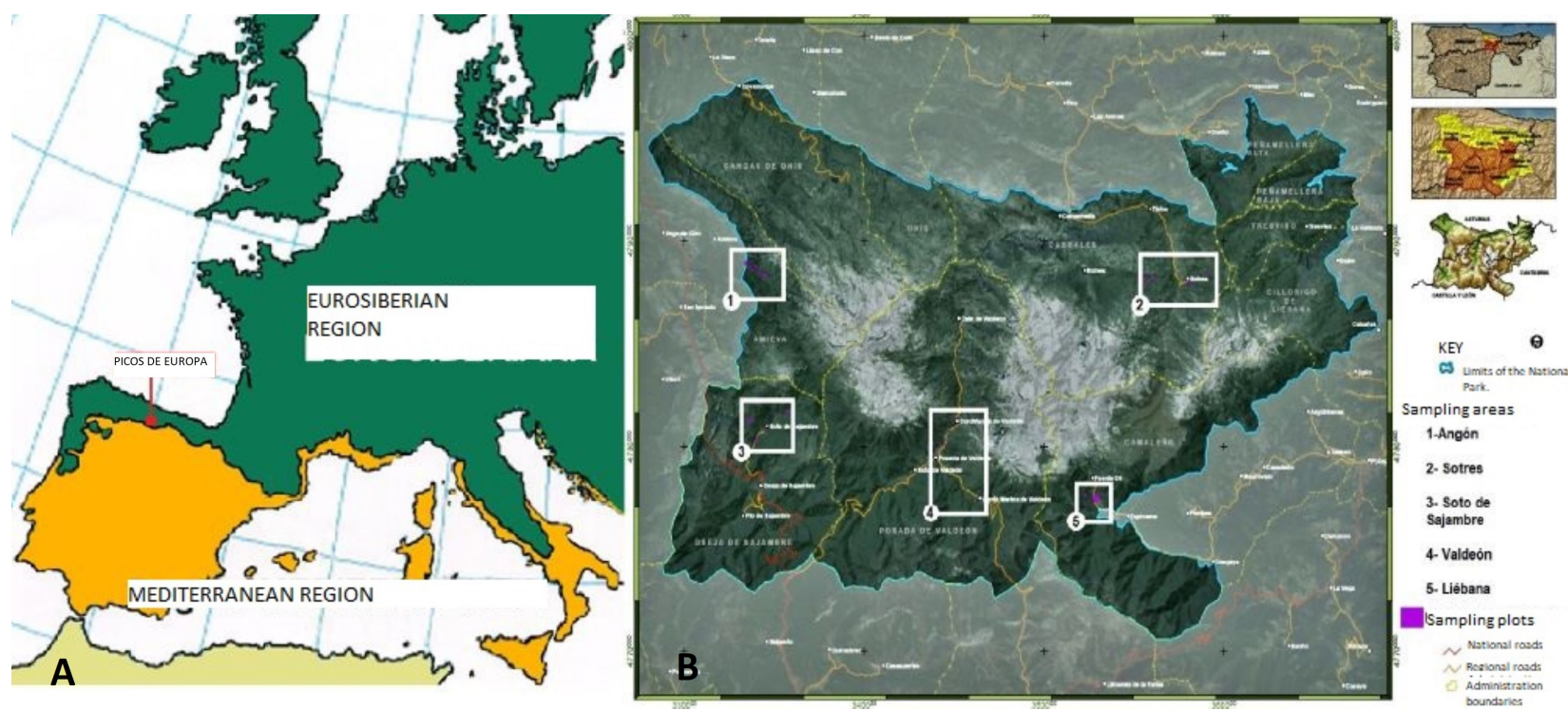

Figure 1. (A): Approximate location of the National Park of Picos de EUROPA. (B): Location of the sampling areas.

Natural and semi-natural grasslands are considered natural habitat types of community interest mentioned in Habitat Directive 92/43 EEC, whose protection requires the designation of special areas of conservation. Special areas of conservation are in danger of disappearance from their natural range, have a restricted natural range (either intrinsically or because of regression), or are remarkable examples of typical characteristics of one of the five following biogeographical regions: Alpine, Atlantic, Continental, Macaronesian and Mediterranean. Mesophile grasslands include lowland meadows (Habitat 6510) and mountain meadows (Habitat 6520). Both habitats are species rich, established on deep, rich soils, maintained by similar human management, though the latter are usually the first to be abandoned because they are more difficult to access [2]. Some characteristic species of Habitat 6510 are grasses like Arrhenatherum elatius, Dactylis glomerata, Poa pratensis, Holcus lanatus, etc and legumes like Trifolium pratense, Lathyrus pratensis or Vicia cracca [1]. Among the most characteristic species of Habitat 6520 are Heracleum sphondylium subsp. pyrenaicum, Astrantia major, Crepis pyrenaica, Polygonum bistorta or Trisetum flavescens. Both habitats share a great number of species, such as D. glomerata, A. elatius, T. pratense, T. repens, Achillea millefolium, Tragopogon pratensis, and so on, which, together with the overlapping of their distribution areas, makes it difficult to differentiate them clearly. The main difference is that habitats 6520 are situated in less accessible locations, at a higher altitude, in places with cooler conditions and more edaphic humidity [2].

Sampling was carried out in June-July 2017 in 25 plots spread about 5 different areas of Picos de Europa: Angón and Sotres in Asturias, Soto de Sajambre and Valdeón in Castilla y León and Liébana in Cantabria (Figure 1B). All meadows belong to the Natura 2000 network and are representative of the typical landscape of Picos de Europa. The main factor for their selection was the fact that all of them are mown in order to harvest the hay in summer and are subject to extensive traditional management. The chosen meadows had to be owned or exploited by farmers willing to be interviewed. Each chosen meadow constituted one plot. The smallest meadows were found in Valdeón, with an average size of 0.06 ha each, while the largest meadows were found in Liébana, with an average size of 0.36 ha. Meadows in the rest of the locations were more similar in size and covered around 0.25 ha each. Altitude ranges from $710 \mathrm{~m}$ to $1270 \mathrm{~m}$; the highest and steepest (14\% on average) meadows are found in the area of Sotres-Pandébano, whereas the lowest meadows with the slightest slopes ( $3 \%$ on 
average) are found in Angón. Annual mean temperature and precipitation was $12{ }^{\circ} \mathrm{C}$ and $1700 \mathrm{~mm}$, respectively, in the highest areas, while in the lowest areas, it was $13^{\circ} \mathrm{C}$ and $800 \mathrm{~mm}$, respectively.

\subsection{Farmers Interviews}

Stakeholders were interviewed $[23,24]$ to determine the type of mowing (with or without use of tractor) and whether or not there was fertilization, either organic or mineral. In total, 14 farmers were interviewed who manage the meadows object of sampling. Only four farmers were owners of the meadows that they used. It is common in the area that the same farmer often manages several meadows, some of which usually belong to other farmers. The interviews either took place at the farmer's home or in the meadows, while they were working, and lasted between thirty and forty-five minutes. According to the information gathered from these interviews, the management of the meadows has remained the same for the last 23 years on average.

\subsection{Edaphic Analyses}

Soil sampling was performed with a Dutch auger at 0-20 cm depth in the center of each plot and each sample was made of a mixture of 5 in situ sub-samples randomly taken by going through the plot in zigzag. None of the selected plots had recently been fertilized. Observable edaphic traits, such as color, compactness or stone content at the surface, were recorded on site.

Once at the laboratory, the samples were spread and dried at room temperature, crumbled with a rolling pin and sieved through a $2 \mathrm{~mm}$ circular mesh. Then, the physical and chemical analyses were carried out. All analyses were performed in duplicate. $\mathrm{pH}$ was measured in $\mathrm{H}_{2} \mathrm{O}$ with a glass electrode in a suspension of soil and water (1:2.5) [25], and the electrical conductivity was measured in the same extract (diluted 1:5). Organic matter was determined by the ignition method [26].

Total $\mathrm{N}$ was determined by a Kjeldahl digestion [27]. Available P was determined colorimetrically with Mehlich 3 reagent [28]. Exchangeable cations ( $\mathrm{K}, \mathrm{Mg}, \mathrm{Na}$ and $\mathrm{Ca}$ ), extracted with $1 \mathrm{M} \mathrm{NH}_{4} \mathrm{Cl}$, and exchangeable aluminium, extracted with $1 \mathrm{M} \mathrm{KCl}$, were determined by atomic absorption spectrophotometry [29]. Effective cation exchange capacity (ECEC) was calculated as the sum of exchangeable cations and exchangeable Al. To determine the calcium carbonate equivalent, first the sample was treated with an excess of acid $(\mathrm{HCl})$ and the amount of $\mathrm{CO}_{2}$ released in the reaction was measured; once the samples had cooled, deionized $\mathrm{H}_{2} \mathrm{O}$ and a phenolphthalein indicator were added; afterwards, the sample was titrated with $\mathrm{NaOH} 1 \mathrm{~N}$; the carbonate is calculated from the amount of base used in the titration [30]. For active calcium carbonate equivalent determination, the samples were agitated with ammonium oxalate $0.2 \mathrm{~N}$ for two hours, then centrifuged, and subsequently the supernatant was titrated with $\mathrm{KMnO}_{4} 0.1 \mathrm{~N}$. This method quantifies the chemically active carbonate fraction, as well as the $\mathrm{Ca}$ in soil solution and adsorbed to the exchange complex. Available boron was calculated by extraction with hot water in a relationship "weight:volume" of 1:2, and visible spectrophotometry using azomethin- $\mathrm{H}$ [31]. Particle-size distribution was determined by the pipette method, and sodium hexametaphosphate and $\mathrm{Na}_{2} \mathrm{CO}_{3}$ were used to disperse the samples [32].

\subsection{Nutrient Analyses}

Plant biomass sampling was carried out in every plot using a metallic square with an area of $0.25 \mathrm{~m}^{2}$ randomly placed on the grass following a trajectory in zigzag and cutting, at ground level, the aerial part of the vegetation within the limits of the square. Three samples were collected in each meadow and then amalgamated into one large sample. To avoid the edge effect (the phenomenon by which borders between adjacent habitats can host different communities from the ones in those habitats [33]), sampling was performed by avoiding the edges of the meadows. During the sampling session, samples were kept in closed bags identified with the date and the code of the corresponding meadow. 
After collection, the samples were directly taken to the lab. The journey back to the lab took around two hours. At the lab, the samples were weighed fresh and then the biomass was separated in three groups according to family: grasses, legumes and other families. The classification in these three groups was done from a $200 \mathrm{~g}$ subsample and then extrapolated to total weight. After this, the samples were dried in an oven at $70{ }^{\circ} \mathrm{C}$ to a constant weight and weighed again. Then, the samples were grinded with an ultracentrifuge rotor mill to obtain a fine powder (sieved with a $0.5 \mathrm{~mm}$ screen) with which the chemical analyses were performed twice in each family group. Wet extraction was done using perchloric acid and nitric acid, subsequently diluted with $\mathrm{HCl} 1 \mathrm{~N}$. In this solution, $\mathrm{Ca}, \mathrm{Mg}$ and $\mathrm{K}$ were determined by atomic absorption and $\mathrm{P}$ photometrically following combustion for $4 \mathrm{~h}$ in a muffle furnace at $450{ }^{\circ} \mathrm{C}$, and dissolution of the ashes with $\mathrm{HCl} 6 \mathrm{~N}$ [34]. Total $\mathrm{N}$ was determined by Kjeldahl digestion [34]. Analyses were performed in duplicate.

\subsection{Statistical Analyses}

To compare the effect of meadow management, the sampling area and groups of species, an ANOVA (Analysis of Variance) test was used. The Tukey test $(p<0.05)$ was applied in the case of significant differences. In addition, to study the relationships among the edaphic variables and the nutrient concentrations in the three family groups (grasses, legumes and other families), a principal component analysis (PCA) with a correlation matrix with the Varimax rotation method was performed. The intercorrelation between edaphic variables and the nutrient concentrations was examined by means of the correlation matrix of the variables and variables that did not correlate with any other variables (singularity) or correlated very highly with one or more variables (multicollinearity) were eliminated from the PCA. The variables retained were reduced to six independent linear combinations, i.e. the principal components (PC) of the variables with eigenvalues greater than 1 , which cumulatively explained $79.8 \%$ of the total variance.

For the study of the influence of the management practices, the plots were distributed in 4 groups: Management 1 corresponds to those plots where the mowing is done with a reaper and there is fertilization (6 plots); Management 2 are those plots mowed with a reaper, but in this case, there is no fertilization (4 plots); Management 3 includes the plots where a tractor is used for mowing and there is fertilization (9 plots); and lastly, Management 4 groups the plots mowed with a tractor but without fertilization (6 plots). 24 [35]

All statistical analyses were performed with the statistical software IBM SPSS Statistics

\section{Results}

\subsection{Farmers Interviews}

Forty-six percent of the meadows do not receive any fertilization beyond that coming from the animals and tractors were used in $58 \%$ of the meadows. All meadows with the exception of one were used for mowing as well as grazing. $88 \%$ of the selected meadows are mowed once a year, with the remaining $12 \%$ mowed a second time some years. Half of the meadows are mowed from the end of July onwards and the other half before mid-July, with some of them being mowed as early as the end of June. In most cases, the time of the first cut depends on the altitude. A summary of the results from the interviews regarding fertilization and mowing are presented in Table 1. A more detailed table has been provided as Supplementary Material (Table S1). 
Table 1. Results from the interviews for fertilization and mowing technique (Source García and García, 2017 [24]).

\begin{tabular}{|c|c|c|}
\hline \multicolumn{2}{|c|}{ Mowing Technique } & \multirow{2}{*}{$\begin{array}{c}\text { Meadows (\%) } \\
21\end{array}$} \\
\hline & Only tractor & \\
\hline \multirow[t]{5}{*}{ Tractor use } & Tractor and/or reaper & 8 \\
\hline & $\begin{array}{c}\text { Tractor and/or reaper }+ \\
\text { scythe }\end{array}$ & 29 \\
\hline & $\begin{array}{l}\text { ythe } \\
\text { on }\end{array}$ & 42 \\
\hline & ure & 38 \\
\hline & & 0 \\
\hline Mar & 1 fertilizer & 8 \\
\hline Slu & fertilizer & 4 \\
\hline & ertilizer & 4 \\
\hline & tion & 46 \\
\hline
\end{tabular}

\subsection{Soil Features and Meadow Management}

Descriptive analyses of the basic properties of the soils are represented in Table 2. pH values ranged from a minimum of 5.2 in Sotres to a maximum of 6.8 in Valdeón (Mean Standard Error $=0.09$ ), covering from strongly acidic to neutral soils. Plots in Angón have the lowest $\mathrm{pH}$ values, below 5.5 (strongly acidic), whereas the plots in Sotres are the ones with more variability, showing values between 5.2 and 6.3. Electrical conductivity in all soils was quite low, fluctuating between a maximum of $0.18 \mathrm{dS} \mathrm{m}^{-1}$ in Liébana (Mean Standard Error $=0.01$ ) and a minimum of $0.05 \mathrm{dS} \mathrm{m}^{-1}$ in Angón, which indicates that these soils have no salinity problems. Regarding texture, the analyzed samples included textures from sandy clay loam to loam, with an average content of clay and sand of $17.1 \%$ and $53.6 \%$, respectively. The content of organic matter in the studied soils was high, with a minimum value of $7.9 \%$ in Valdeón and a maximum of $15.9 \%$ in Angón. Regarding nitrogen, all soils showed a very high content of this nutrient and the minimum (1.1\%) as well as the maximum (3.12\%) appeared in the area of Liébana. All plots showed a low $\mathrm{C} / \mathrm{N}$ relationship, with a maximum value of 7.2 in Liébana.

Table 2. Descriptive statistics for the soil general properties and mean values of dry biomass and nutrients concentrations in the meadows.

\begin{tabular}{|c|c|c|c|c|c|}
\hline Parameters & Min. & Max. & Mean & Mean Standard Error & Standard Deviation \\
\hline Soil properties $\mathrm{pH}^{1}$ & 5.2 & 6.8 & 5.9 & 0.09 & 0.42 \\
\hline $\mathrm{EC}^{2}\left(\mathrm{dS} \mathrm{m}^{-1}\right)$ & 0.04 & 0.18 & 0.10 & 0.01 & 0.03 \\
\hline $\mathrm{OM}^{3}(\%)$ & 7.9 & 15.9 & 11.7 & 0.33 & 1.66 \\
\hline $\mathrm{N}(\%)$ & 1.1 & 3.1 & 1.9 & 0.11 & 0.52 \\
\hline $\mathrm{C} / \mathrm{N}$ & 2.0 & 7.2 & 3.8 & 0.21 & 1.05 \\
\hline Clay (\%) & 8.9 & 34.6 & 17.1 & 1.36 & 6.80 \\
\hline Sand $(\%)$ & 29.6 & 75.4 & 53.6 & 2.54 & 12.70 \\
\hline $\mathrm{PM}^{4}\left(\mathrm{mg} \mathrm{kg}^{-1}\right)$ & 23.7 & 53.9 & 39.9 & 1.51 & 7.54 \\
\hline $\mathrm{Ca}\left(\mathrm{mol} \mathrm{kg}^{-1}\right)$ & 0.03 & 0.08 & 0.06 & 0.29 & 1.43 \\
\hline $\mathrm{K}\left(\mathrm{mol} \mathrm{kg}{ }^{-1}\right)$ & 0.002 & 0.01 & 0.005 & 0.06 & 0.27 \\
\hline $\mathrm{Mg}\left(\mathrm{mol} \mathrm{kg}^{-1}\right)$ & 0.009 & 0.04 & 0.02 & 0.16 & 0.78 \\
\hline $\mathrm{Na}\left(\mathrm{mol} \mathrm{kg}^{-1}\right)$ & 0.01 & 0.02 & 0.02 & 0.03 & 0.16 \\
\hline $\mathrm{Al}\left(\mathrm{mol} \mathrm{kg}^{-1}\right)$ & 0.01 & 0.03 & 0.02 & 0.14 & 0.67 \\
\hline $\operatorname{ECEC}^{5}\left(\mathrm{~mol} \mathrm{~kg}^{-1}\right)$ & 0.08 & 0.15 & 0.12 & 0.34 & 1.68 \\
\hline $\mathrm{CCE}^{6}(\%)$ & 1.5 & 6.5 & 3.0 & 0.22 & 1.11 \\
\hline $\operatorname{ACCE}^{7}(\%)$ & 0.32 & 2.3 & 1.5 & 0.10 & 0.47 \\
\hline $\mathrm{B}^{8}\left(\mathrm{mg} \mathrm{kg}^{-1}\right)$ & 3.7 & 5.1 & 4.4 & 0.07 & 0.36 \\
\hline Bulk Density $\left(\mathrm{g} \mathrm{cm}^{-3}\right)$ & 1.3 & 1.6 & 1.5 & 0.01 & 0.06 \\
\hline $\begin{array}{l}\text { Dry matter and mean values } \\
\text { of nutrients in the meadows } \\
\qquad \operatorname{DM}^{9}(\%)\end{array}$ & 8.8 & 32.6 & 23.7 & 1.04 & 5.68 \\
\hline
\end{tabular}


Table 2. Cont.

\begin{tabular}{cccccc}
\hline Parameters & Min. & Max. & Mean & Mean Standard Error & Standard Deviation \\
\hline $\begin{array}{c}\text { DM production } \\
\left(\mathrm{kg} \mathrm{ha}^{-1}\right)\end{array}$ & 1416 & 7277 & 3543 & 286 & 1432 \\
$\mathrm{~N} \mathrm{( \% )}$ & 1.2 & 2.8 & 2.1 & 0.77 & 3.86 \\
$\mathrm{P}(\%)$ & 0.5 & 1.3 & 0.8 & 0.41 & 2.06 \\
$\mathrm{Ca} \mathrm{( \% )}$ & 0.2 & 1.0 & 0.5 & 0.55 & 2.72 \\
$\mathrm{Mg}(\%)$ & 0.2 & 0.7 & 0.3 & 0.30 & 0.53 \\
$\mathrm{~K}(\%)$ & 0.4 & 0.7 & 0.5 & 0.13 & 0.62 \\
\hline
\end{tabular}

${ }^{1} \mathrm{pH}\left(\mathrm{H}_{2} \mathrm{O}\right)$ soil:solution (1:2.5); ${ }^{2}$ Electrical conductivity (1:5) measured at $25{ }^{\circ} \mathrm{C} ;{ }^{3}$ Organic matter; ${ }^{4}$ Available P extracted by Mehlich 3 method; ${ }^{5}$ Effective Cation Exchange Capacity; ${ }^{6}$ Calcium carbonate equivalent; ${ }^{7}$ Active Calcium Carbonate Equivalent; ${ }^{8}$ Available boron; ${ }^{9}$ Dry matter.

In the case of available phosphorus, all plots showed levels of phosphorus over the critical threshold for extractant Mehlich 3 (30 $\mathrm{mg} \mathrm{P} \mathrm{kg}^{-1}$ ) [28], except two plots in Liébana with values of $24.7 \mathrm{mg} \mathrm{P} \mathrm{kg}^{-1}$ and $23.7 \mathrm{mg} \mathrm{P} \mathrm{kg}^{-1}$. Exchangeable cations and effective cation exchange capacity (ECEC) increased with the percentage of colloids in the soils, being the highest value of $0.15 \mathrm{~mol} \mathrm{~kg}^{-1}$ in Liébana and the lowest of $0.08 \mathrm{~mol} \mathrm{~kg}^{-1}$ in the same area. The Ca: $\mathrm{Mg}$ relationship in the studied soils showed its highest value (8.2) in Sotres. For the relationship K:Mg, two of the plots in Valdeón showed values higher than 0.5 and up to nine plots spread along the five areas of study showed values under 0.2.

The percentage of calcium carbonate equivalent turned out to be very low, in line with the contents usually presented by acidic soils. Accordingly, active calcium carbonate equivalent percentage was low in all analyzed plots, with a maximum of 2.3 in Sotres. Regarding levels of available boron, the majority of the plots showed concentrations between 1 and $5 \mathrm{mg} \mathrm{B} \mathrm{kg}^{-1}$, except two plots in Liébana, which showed concentrations over $5 \mathrm{mg} \mathrm{B} \mathrm{kg}^{-1}$.

The results of the analysis of variance in relation to the study areas (Asturias, León and Cantabria) showed significant differences in eight parameters (Table 3). The ANOVA test itself provides only statistical evidence of a difference, but not any statistical evidence as to which mean or means are statistically different. We used a multiple comparison technique (Tukey test at 95\% confidence) in ANOVA when we had a significant difference. Each of the factor levels were associated with a grouping letter. If any factor levels have the same letter, then the multiple comparison method did not determine a significant difference between the mean responses. For any factor levels that do not share a letter, a significant mean difference was identified. In Table 3, pH in Cantabria is identified with an "a", which means that it is significantly different to $\mathrm{pH}$ in Asturias, identified with a " $\mathrm{b}$ ", but not significantly different to $\mathrm{pH}$ in León, identified with " $\mathrm{ab}^{\prime}$ ". The highest values of $\mathrm{pH}, \mathrm{C} / \mathrm{N}$ ratio, exchangeable $\mathrm{K}$ and $\mathrm{Mg}$, available boron content and sand were found in the plots of Liébana in Cantabria $(\mathrm{F}=4.863, p<0.05 ; \mathrm{F}=4.437, p<0.05 ; \mathrm{F}=4.735, p<0.05 ; \mathrm{F}=4.735, p<0.05 ; \mathrm{F}=3.087, p<0.05 ;$ $\mathrm{F}=18.993, p<0.001$ respectively), while in the case of available $\mathrm{P}$ and exchangeable $\mathrm{Al}$, the highest values appeared in Asturias $(\mathrm{F}=7.766, p<0.01 ; \mathrm{F}=11.139, p<0.001$, respectively).

Table 3. Mean values of the soil properties with significant differences according to the zone.

\begin{tabular}{|c|c|c|c|c|}
\hline ZONE & $\mathrm{pH}^{1}$ & $\mathrm{C} / \mathrm{N}$ & $\mathrm{PM}^{2}\left(\mathrm{mg} \mathrm{kg}^{-1}\right)$ & Exchangeable $\mathrm{K}\left(\mathrm{mol} \mathrm{kg}^{-1}\right)$ \\
\hline Asturias & $5.7 \mathrm{~b}(0.41)$ & $3.3 \mathrm{~b}(0.72)$ & 45.7 a $(3.82)$ & $0.004 \mathrm{~b}(0.14)$ \\
\hline León & $6.1 \mathrm{ab}(0.40)$ & $3.8 \mathrm{ab}(0.63)$ & $36.8 \mathrm{~b}(4.79)$ & $0.005 \mathrm{~b}(0.31)$ \\
\hline Cantabria & 6.2 a $(0.15)$ & 4.8 a (1.63) & $34.8 \mathrm{~b}(10.76)$ & 0.008 a $(0.24)$ \\
\hline ZONE & Exchangeable $\mathrm{Mg}$ (mol kg ${ }^{1}$ ) & Exchangeable Al (mol kg ${ }^{1}$ ) & Boron $\left(\mathrm{mg} \mathrm{kg}^{-1}\right)$ & Sand $(\%)$ \\
\hline Asturias & $0.02 \mathrm{~b}(0.45)$ & 0.03 a $(0.75)$ & $4.2 \mathrm{~b}(0.39)$ & $54.4 \mathrm{~b}(9.88)$ \\
\hline León & $0.02 \mathrm{ab}(0.66)$ & $0.02 \mathrm{~b}(0.22)$ & $4.4 \mathrm{ab}(0.26)$ & $44.1 \mathrm{~b}(7.36)$ \\
\hline Cantabria & 0.03 a (1.1) & $0.02 \mathrm{~b}(0.07)$ & 4.7 a $(0.35)$ & 71.1 a (3.69) \\
\hline
\end{tabular}

Statistical significance is indicated with different letters, letter " $a$ " indicating significantly greater values than letter " $b$ ". Means in a column with no common letters are significantly different, Tukey test, $p<0.05$. Standard deviations are shown in brackets. ${ }^{1} \mathrm{pH}\left(\mathrm{H}_{2} \mathrm{O}\right)$ soil:solution $(1: 2.5) ;^{2}$ Available P in the soil extracted by the Mehlich 3 method. 
The results of ANOVA with management practices as control variable showed significant differences in five edaphic parameters and two foliar nutrients (Table 4). The highest values of $\mathrm{pH}$, electrical conductivity and exchangeable $\mathrm{Ca}(\mathrm{F}=6.684, p<0.01 ; \mathrm{F}=5.163$, $p<0.01 ; \mathrm{F}=0.471, p<0.05$, respectively) were found in unfertilized meadows, while the highest values for exchangeable $\mathrm{K}$ and sand percentage $(\mathrm{F}=2.839, p>0.05 ; \mathrm{F}=17.015$, $p<0.001$, respectively) were found in fertilized meadows. In all these cases, the plots with the highest values were mowed without a tractor.

Table 4. Mean values of the soil properties and foliar nutrient contents with significant differences according to meadow management.

\begin{tabular}{|c|c|c|c|c|c|c|c|}
\hline MANAGE. ${ }^{1}$ & $\mathrm{pH}^{2}$ & $\begin{array}{c}\mathrm{EC}^{3} \\
\mathrm{dS} \mathrm{m}^{-1}\end{array}$ & $\begin{array}{l}\text { Exchangeable } \\
\text { Ca mol kg }\end{array}$ & $\begin{array}{l}\text { Exchangeable } \\
\mathrm{K} \mathrm{mol} \mathrm{kg}^{-1}\end{array}$ & Sand \% & GFP $^{4 \%}$ & GFK $^{5} \%$ \\
\hline 1 & 6.1ab (0.39) & $0.11 \mathrm{ab}(0.11)$ & $0.06 \mathrm{ab}(5.61)$ & 0.007 a $(0.36)$ & $71.1 \mathrm{a}(3.67)$ & $0.6 \mathrm{ab}(2.15)$ & $0.5 \mathrm{ab}(0.52)$ \\
\hline 2 & 6.4 a (0.34) & 0.15 a $(0.15)$ & 0.07 a (0.82) & $\begin{array}{c}0.006 \mathrm{ab} \\
(0.30)\end{array}$ & 50.8 bc (4.34) & $0.5 \mathrm{~b}(0.95)$ & $0.5 \mathrm{ab}(0.84)$ \\
\hline 3 & $5.6 \mathrm{~b}(0.36)$ & 0.09 b (0.09) & $0.05 \mathrm{~b}(1.48)$ & $\begin{array}{c}0.006 \mathrm{ab} \\
(0.23)\end{array}$ & 55.6 b (10.77) & 0.9 a (3.23) & 0.6 a (0.46) \\
\hline 4 & $5.9 \mathrm{~b}(0.20)$ & $0.08 \mathrm{~b}(0.08)$ & $0.06 \mathrm{ab}(1.31)$ & $0.003 \mathrm{~b}(0.07)$ & 40.9 c (5.59) & $0.6 \mathrm{ab}(0.94)$ & $0.5 \mathrm{~b}(0.75)$ \\
\hline
\end{tabular}

Statistical significance is indicated with different letters, letter " $a$ " indicating significantly greater values than letter " $b$ ". Means in a column with no common letters are significantly different, Tukey test, $p<0.05$. Standard deviations are shown in brackets. ${ }^{1}$ Managements: (1) Reaper + Fertilization, (2) Reaper, no fertilization, (3) Reaper+Tractor+Fertilization and (4) Reaper+Tractor, no fertilization; ${ }^{2} \mathrm{pH}\left(\mathrm{H}_{2} \mathrm{O}\right)$ soil:solution (1:2.5); ${ }^{3}$ Electrical conductivity (1:5) measured at $25^{\circ} \mathrm{C} ;{ }^{4}$ Foliar content of $\mathrm{P}$ in grasses; ${ }^{5}$ Foliar content of $\mathrm{K}$ in grasses.

\subsection{Dry Matter and Nutrient Concentration in Grasses, Legumes and Other Families}

The group "grasses" was composed of different genera belonging to the family Poaceae, many of which are representative of the concerned habitats, such as Arrhenatherum, Dactylis, Agrostis, Holcus, Trisetum, etc. The group "legumes" included several species from five genus from the family Fabaceae: Trifolium, Vicia, Lotus, Medicago and Lathyrus. The group "other families" included species from any other family: Asteraceae, Apiaceae, Rosaceae, Lamiaceae, Malvaceae, etc. In this last group, the family Asteraceae was the one with a higher number of species present in the sample, followed by Apiaceae. However, other families were represented by only one or two species, such as Linaceae or Caprifoliaceae.

The average content in dry matter oscillated between a minimum of $8.8 \%$ (Table 2, Mean Standard Error $=1.04$ ) and a maximum of $32.6 \%$. The three groups had their maximum values of dry matter in plots in Valdeón, these being $37.8 \%$ for the grasses, $32.2 \%$ for the legumes (these values appeared in the same plot) and $46.9 \%$ for the group of other families. The minimum values appeared in Angón for grasses, with a value of $19.6 \%$, in Valdeón for legumes, with a value of $6.9 \%$ and in Liébana for the group of other families, with a value of $6.8 \%$.

The average content of foliar $\mathrm{N}$ was $2.1 \%$, with a minimum of $1.2 \%$ and a maximum of $2.8 \%$ (Table 2). However, it is worth noting that these are the values that showed the greatest dispersion among the foliar nutrients, as indicated by the standard deviation (3.86). Looking into the results by families (Table 5), both the minimum and maximum values for foliar $\mathrm{N}(0.6 \%$ and $4.2 \%)$ were found in the group of grasses in Angón and Sotres, respectively. The average content in $\mathrm{P}$ showed a mean value of $0.8 \%$, with a maximum of $1.3 \%$ and a minimum of $0.5 \%$. Similarly to $\mathrm{N}$, the highest $(1.4 \%)$ and the lowest $(0.4 \%)$ values attending to the groups of families appeared in grasses, this time in Valdeón and Sotres, respectively. For the average content of $\mathrm{Ca}$, a minimum of $0.2 \%$ and a maximum of $1 \%$ were found, with the mean value being $0.5 \%$. The group that contained the highest amount of Ca was the group of other families, with a value of $1.4 \%$ in a plot in Liébana. Concerning $\mathrm{Mg}$ average content, the lowest value was $0.2 \%$ and the highest was $0.7 \%$, with a mean value of $0.3 \%$. For the groups of families, the minimum was $0.1 \%$ in the legumes and the maximum was $0.8 \%$ in the group of other families. However, the dispersion values were not very high (Table 5). Both the maximum and the minimum values were found in plots in Valdeón. 
Table 5. Descriptive statistics for the duplicated analyses of leaf nutrient concentrations separated by family.

\begin{tabular}{|c|c|c|c|c|c|}
\hline Foliar Nutrients by Family \% & Min. & Max. & Mean & Mean Standard Error & Standard Deviation \\
\hline \multicolumn{6}{|l|}{ Grasses } \\
\hline $\mathrm{N}$ & 0.6 & 4.2 & 1.2 & 1.87 & 9.37 \\
\hline $\mathrm{P}$ & 0.4 & 1.4 & 0.7 & 0.50 & 2.51 \\
\hline $\mathrm{Ca}$ & 0.3 & 0.5 & 0.4 & 0.11 & 0.53 \\
\hline $\mathrm{Mg}$ & 0.3 & 0.6 & 0.5 & 0.17 & 0.83 \\
\hline $\mathrm{K}$ & 0.4 & 0.7 & 0.5 & 0.16 & 0.77 \\
\hline \multicolumn{6}{|l|}{ Legumes } \\
\hline $\mathrm{N}$ & 1.4 & 3.2 & 2.3 & 0.80 & 4.02 \\
\hline $\mathrm{P}$ & 0.5 & 1.2 & 0.8 & 0.43 & 2.16 \\
\hline $\mathrm{Ca}$ & 0.1 & 1.4 & 0.6 & 1.15 & 5.75 \\
\hline $\mathrm{Mg}$ & 0.1 & 0.8 & 0.3 & 0.54 & 2.70 \\
\hline K & 0.4 & 0.7 & 0.5 & 0.16 & 0.82 \\
\hline \multicolumn{6}{|l|}{ Other families } \\
\hline $\mathrm{N}$ & 1 & 3.9 & 2 & 1.12 & 5.58 \\
\hline $\mathrm{P}$ & 0.5 & 1.7 & 0.9 & 0.51 & 2.56 \\
\hline $\mathrm{Ca}$ & 0.1 & 1.4 & 0.4 & 0.90 & 4.51 \\
\hline $\mathrm{Mg}$ & 0.1 & 0.8 & 0.3 & 0.62 & 3.11 \\
\hline $\mathrm{K}$ & 0.4 & 0.6 & 0.5 & 0.13 & 0.63 \\
\hline
\end{tabular}

The average content in $\mathrm{K}$ fluctuated between a minimum of $0.4 \%$ and a maximum of $0.7 \%$, with a mean of $0.5 \%$. K values were the ones with the least dispersion (Standard Deviation $=0.62$, Table 1$)$. Considering the different families, the highest value $(0.7 \%)$ appeared in the group of legumes in Angón and the lowest (0.4\%) in the grasses in Valdeón.

The percentage of dry matter, as well as the foliar concentrations of $\mathrm{P}$ and $\mathrm{Mg}$, were significantly different among the different groups of species (Table 6) $(\mathrm{F}=17.37, p<0.001$; $\mathrm{F}=2.91, p<0.05$ and $\mathrm{F}=4.651, p<0.05$, respectively). The highest values for dry matter and $\mathrm{Mg}$ were found in the grasses, while the highest concentrations of $\mathrm{P}$ were found in the group of other families.

Table 6. Mean values of dry matter (DM) and nutrient concentrations with significant differences in grasses, legumes and other families.

\begin{tabular}{cccc}
\hline Species Group & DM (\%) & $\mathbf{P ~ ( \% )}$ & Mg (\%) \\
\hline Grasses & $29.4 \mathrm{a}(4.53)$ & $0.7 \mathrm{~b}(2.52)$ & $0.5 \mathrm{a}(0.83)$ \\
Legumes & $20.2 \mathrm{~b} \mathrm{(7.05)}$ & $0.8 \mathrm{ab}(2.17)$ & $0.3 \mathrm{~b}(2.71)$ \\
Other families & $20.0 \mathrm{~b}(7.21)$ & $0.9 \mathrm{a}(2.58)$ & $0.3 \mathrm{ab}(3.12)$ \\
\hline
\end{tabular}

Statistical significance is indicated with different letters, letter "a" indicating significantly greater values than letter " $b$ ". Means in a column with no common letters are significantly different, Tukey test, $p<0.05$. Standard deviations are shown in brackets.

As stated above, the foliar content of two nutrients was affected by management type (Table 4). These nutrients were $\mathrm{P}$ and $\mathrm{K}(\mathrm{F}=3.579, p<0.05 ; \mathrm{F}=4.632, p<0.05$ respectively) and this influence only appeared in the family of grasses. Both foliar $\mathrm{P}$ and foliar $\mathrm{K}$ reached the highest values in fertilized plots where the tractor was used.

The results of the principal components analysis are shown in Figure 2 as a projection of the variables on the plot of components $1-2$ ( $42.4 \%$ of the total variance explained). Some variables $(\mathrm{C} / \mathrm{N}, \mathrm{Ca}: \mathrm{Mg}, \mathrm{Al})$ were eliminated from the analysis in order to avoid distortion of the results due to their high correlation with other variables (total $\mathrm{N}$, exchangeable $\mathrm{Ca}$ and $\mathrm{Mg}$, and $\mathrm{pH}$, respectively). On the positive side of the first $\mathrm{PC}$, the foliar contents of $\mathrm{P}$ and $\mathrm{K}$ in grasses (FPGR, FKGR), legumes (FPLE, FKLE) and other families (FPOF, FKOF) and also the foliar content of $\mathrm{Mg}$ in grasses (FMgGR) were positively correlated with soil $\mathrm{K}$ content and the organic matter percentage in the soil. On the positive side of the second $\mathrm{PC}$, the foliar contents of $\mathrm{Ca}$ and $\mathrm{Mg}$ in legumes (FCaLE, FMgLE) and in other families 
(FCaOF, FMgOF) were positively correlated with total nitrogen in the soil and negatively correlated with soil $\mathrm{Ca}$ and $\mathrm{Mg}$ contents and $\mathrm{pH}$.

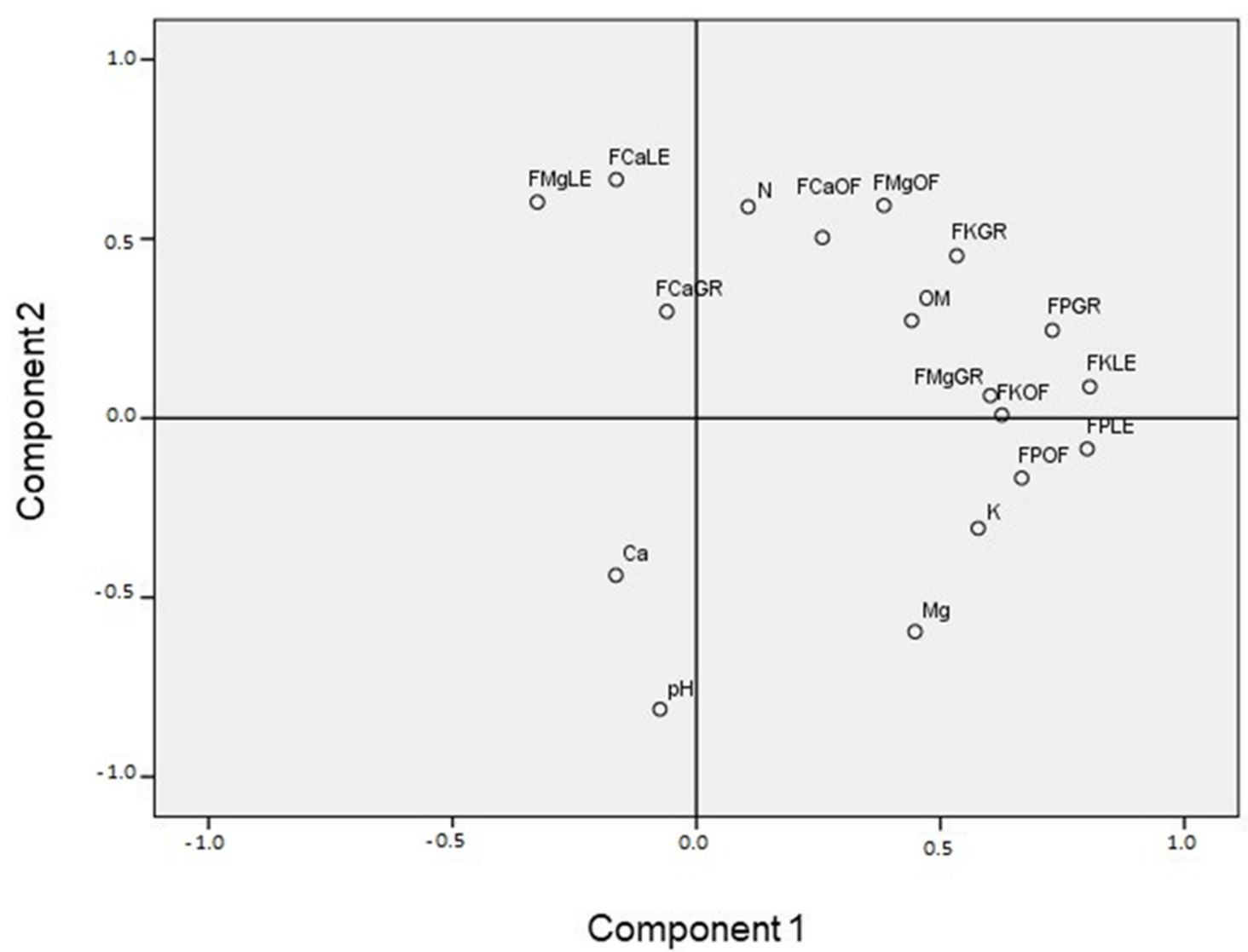

Figure 2. Plot of the principal component analysis with projection of the soil and foliar variables; component 1 as $\mathrm{x}$ axis and component 2 as y axis (44.2\% of the total variance explained). FMgLE: foliar Mg in legumes; FCaLE: foliar Ca in legumes; FKLE: foliar K in legumes; FPLE: foliar P in legumes, FMgGR: foliar Mg in grasses; FCaGR: foliar Ca in grasses; FKGR: foliar $\mathrm{K}$ in grasses; FPGR: foliar P in grasses; FMgOF: foliar Mg in other families, MCaOF: foliar Ca in other families; FKOF: foliar $\mathrm{K}$ in other families; FPOF: foliar P in other families; OM: organic matter; $\mathrm{N}$ : total soil $\mathrm{N}$; $\mathrm{Ca}, \mathrm{Mg}, \mathrm{K}$ : exchangeable Ca, $\mathrm{Mg}$ and $\mathrm{K}$ in the soil.

The results of the PCA analysis show that $\mathrm{pH}$ was the edaphic variable with the highest proportion of variance explained (highest communality) by the two principal components. $\mathrm{K}$ and $\mathrm{P}$ content in legumes were the foliar variables with the highest proportion of variance explained by the two principal components (Table S2, Supplementary Materials).

\section{Discussion}

\subsection{Soil Features and Meadow Management}

The results of the analyses of the soil properties of the hay meadows studied for this project correspond with the range of values characteristic of humid temperate climate zones [36]. The high values of organic matter are consistent with those usually found in hay meadows in these areas [37]. The low values of $\mathrm{C} / \mathrm{N}$ found in all the plots point to a fast mineralization of the organic matter with a good production of inorganic nitrogen. The threshold for inorganic $\mathrm{N}$ release is a $\mathrm{C} / \mathrm{N}$ around 15:1 [38]. A C/N under 10 indicates a good inorganic $\mathrm{N}$ production [38]. However, the low $\mathrm{C} / \mathrm{N}$ ratio observed in our results is not necessarily an indicator of increased nitrogen availability, bearing in mind the rapid $\mathrm{N}$ loss by lixiviation and its incorporation into certain chemical structures that are hard to break down [33]. 
It is significant that 23 out of the 25 plots showed values for available P over $30 \mathrm{mg} \mathrm{P} \mathrm{kg}^{-1}$, some of them reaching high concentrations, despite the fact that a good proportion of these plots were unfertilized (Excel Spreadsheet 2, Picos de Europa Soil Database, Supplementary Materials).

While the relationship Ca:Mg was clearly balanced, $\mathrm{K}: \mathrm{Mg}$ ratio showed values under 0.2 in nine plots (Excel Spreadsheet 2, Picos de Europa Soil Database, Supplementary Materials), which indicates either a lack of $\mathrm{K}$ or an excess of $\mathrm{Mg}$ [39].

Effective cation exchange capacity determined at soil $\mathrm{pH}$ is a measure of soil quality that depends greatly on soil texture and organic matter [40]. It represents the capability of the soil to attract and retain exchangeable cations ( $\mathrm{K}, \mathrm{Ca}, \mathrm{Mg}$, etc.) [40]. High contents of organic matter and clay have a large number of negative charges that hold adsorbed cations, which causes ECEC to increase [40]. Several authors have reported evidence of these relationships in different countries and soils. Cation exchange capacity has been found to be higher in soils where clay content is greater [40]. However, in some soils, the correlation between ECEC and clay is negative [12]. In Asturias, ECEC has been found to vary accordingly to clay percentage [41]. Correlations between ECEC and clay are dependent on the mineralogy of clay. Non-expandable clays have low negative charges, and therefore, low CEC, which can explain the lack of correlation between ECEC and clay content $[42,43]$.

The differences in geographic location, altitude and environmental conditions among the meadows account for a certain variability, not only in species composition, but also in their chemical characteristics. Liébana showed the highest concentrations for exchangeable $\mathrm{K}$ and $\mathrm{Mg}$ (Table 3, $p<0.05$ ). For available $\mathrm{P}$ and exchangeable $\mathrm{Al}$ the highest values appeared in Asturias, which were the more strongly acidic soils, as was clearly stated by the ANOVA and Tukey tests (Table $3, p<0.05$ ). This is unexpected due to the higher $\mathrm{P}$ sorption capacities of low-pH soils. Strongly acidic soils are usually deficient in $\mathrm{P}$, as well as other nutrients [44]. The high concentrations of $\mathrm{P}$ in acidic soils may be explained by leaching favored by abundant precipitations. This produces an increase in the exchangeable $\mathrm{Al}$ in the arable layer by displacing other cations, but, due to its higher adhesion to soil organic and inorganic compounds, phosphorus would not be displaced like other elements, and consequently, its availability would not be reduced [45].

Regarding the ANOVA test with management practices as a control variable, the results show that the highest values of $\mathrm{pH}$, conductivity and exchangeable $\mathrm{Ca}$ were found in unfertilized plots, while the highest values of exchangeable $\mathrm{K}$ and sand percentage were found in fertilized plots (Table $4, p<0.05$ ). One reason for low $\mathrm{pH}$ in fertilized areas could be the repeated application of ammonium based fertilizers, which, upon oxidation, produce strong inorganic acids, which in turn release $\mathrm{H}^{+}$ions, lowering the soil $\mathrm{pH}$ [13]. The higher values of $\mathrm{pH}$ and exchangeable $\mathrm{Ca}$ in acidic, non-fertilized soils with a high organic matter content could be explained by mineralization and subsequent release of the exchangeable bases present in organic compounds, and the high $\mathrm{N}$ content associated with the formation of $\mathrm{NH}_{4}{ }^{+}$, which consumes protons [46]. Following nitrification from $\mathrm{NH}_{4}{ }^{+}$to $\mathrm{NO}_{3}{ }^{-}$would be inhibited [46] and $\mathrm{pH}$ would not decrease. Values of soil $\mathrm{N}$ and $\mathrm{P}$ in fertilized meadows were not significantly different from those in unfertilized meadows. The fact that the results of the ANOVA test do not show any effect of management on soil P concentration indicates that fertilization is not influencing the apparently high availability of $\mathrm{P}$ in the soil. In so far as soil $P$ values are more or less the same regardless of the fertilization status of the meadows, it suggests the option to review the management of $P$ fertilizers in these areas. With such values as are seen here, P cannot be considered limiting; hence, there probably will not be a yield response to continuous fertilization. It is possible that the high amounts of organic matter on these areas account for the high concentrations of $\mathrm{P}$ and $\mathrm{N}$ in the soil, though these also could respond to the management history in the area. It has been suggested that the effects of $\mathrm{P}$ and $\mathrm{N}$ fertilizers on the distribution of $\mathrm{P}$ may last for a long period $[15,19]$. Plant $P$ uptake is affected by different soil properties, among which is the soil buffer capacity (which mainly depends on organic matter content and cation exchange 
capacity), pH or clay content [47]. Different authors [47-49] have found different critical levels of $\mathrm{P}$ (those levels over which there is no plant response to $\mathrm{P}$ addition) for different extractants depending on the soil and type of crop.

Tractor use alone only affected $\mathrm{pH}$, which was highest in the plots where it was not used (Table S3, Supplementary materials, ANOVA, F $=9.263, p<0.001$ ). Fertilization alone affected sand percentage, foliar $\mathrm{P}$ content in grasses and foliar $\mathrm{K}$ content in grasses, with the highest sand percentage belonging to plots where organic fertilizer was applied and the highest contents of $\mathrm{P}$ and $\mathrm{K}$ in grasses in plots where both organic and mineral fertilizers were used (Table S3, Supplementary materials, ANOVA, F = 10.516, $p<0.001$ for sand percentage; $\mathrm{F}=5.182, p<0.05$ for foliar $\mathrm{P} ; \mathrm{F}=4.716, p<0.05$ for foliar $\mathrm{K}$ ). For the rest of the parameters that were influenced by management practices (conductivity, exchangeable $\mathrm{Ca}$ and exchangeable $\mathrm{K}$ ), it must be the combined effects of the management techniques (fertilization or not combined with tractor use or reaper for mowing) that explain the effects on soil properties. The highest values of $\mathrm{pH}$ and exchangeable $\mathrm{Ca}$ appeared in meadows where neither tractor nor fertilization was used, while in the case of exchangeable $\mathrm{K}$ the highest values appeared in fertilized meadows, also without tractor utilization (Table $4, p<0.05$ ). Several experiments have reported an important influence of land use and fertilization on soil properties, such as nitrogen content, available $\mathrm{P}$ and exchangeable cations $[12,13,15,41,50]$.

There were two plots in Liébana that presented what could be toxic values of boron, just over $5 \mathrm{mg} \mathrm{kg}^{-1}$. Liébana, in Cantabria, exhibited significantly higher values than other sites (Table 3, $p<0.05$ ). However, these high concentrations are unlikely to cause adverse effects [51].

\subsection{Dry Matter and Nutrient Concentration in Grasses, Legumes and Other Families}

The concentrations of nutrients in the plant biomass differ from those given by Epstein as adequate for a correct development of the plants [52] (Table S5, Supplementary materials). Particularly, phosphorus was present in much higher concentrations than would be expected, which responds to the high concentrations of soil available P. Foliar N concentrations would also be considered high. Values for foliar K in the three groups of families are around half of what is considered adequate [52]. These low values indicate low soil K availability, as suggested by the low soil K:Mg ratio (Excel Spreadsheet 2, Picos de Europa Soil Database, Supplementary materials). However, its levels stayed within the range $0.5-2 \%$ in dry matter, which is the critical $\mathrm{K}$ threshold for many plants [53]. It has been reported that the critical concentration of $\mathrm{K}$ would decrease if the rate of supply of other cations, such as $\mathrm{Na}$ and $\mathrm{Mg}$, were increased [53]. In this study, $\mathrm{Mg}$ concentrations, especially in the groups of grasses, are above the $2 \mathrm{mg} \mathrm{g}^{-1}$ given by Epstein [52] (Table S5, Supplementary materials, T-test, $\mathrm{t}=15.402, p<0.001)$. Previous work comparing the nutritional status of plants across a wide range of species and soils (Foulds [54]) found $\mathrm{N}$ and $\mathrm{K}$ to be the most concentrated of the macronutrients and $\mathrm{P}$ the least, with $\mathrm{Ca}$ and $\mathrm{Mg}$ being more variable. Another study on plant nutrient concentrations by Thompson et al. [55] focused on herbaceous flora and had the same results. In our study, P concentration was the only disparity from this outline, being the most concentrated nutrient after $\mathrm{N}$ and followed by K.

Management appears to have an effect on the concentration of $\mathrm{P}$ and $\mathrm{K}$ in the leaves only among grasses. According to our results, the most intensive management (tractor use + fertilization) increases the uptake of $\mathrm{P}$ and $\mathrm{K}$ (Table 4 , ANOVA, F $=3.579$ for $\mathrm{P}$ and $\mathrm{F}=4.632$ for $\mathrm{K}, p<0.05)$. In pastures on $\mathrm{K}$ deficient soils, grasses have been shown to be more efficient at securing their potassium needs than associated clovers [56]. This could imply that, on $\mathrm{K}$ deficient soils, grasses would take more advantage than legumes when fertilized. Some authors have previously found that $\mathrm{P}$ and $\mathrm{K}$ content in the grass increases significantly in hay meadows with both nitrogen and phosphate fertilization [57].

The results showed that the $\mathrm{pH}$ negatively correlated to foliar $\mathrm{Ca}$ in the groups of legumes and other families (Table S4, Supplementary materials, Pearson coefficient $\left.-0.421^{*}, p<0.05\right)$. It has been previously found that $\mathrm{Ca}$ and $\mathrm{K}$ uptake would improve with 
rising $\mathrm{pH}$ in hay meadows in mountain passes in Asturias [37]. This, in turn, increases cation exchange capacity and therefore liming could enhance the mineral quality of the pasture [37]. Thompson et al. [55] also found a consistent positive correlation between foliar $\mathrm{Ca}$ and $\mathrm{pH}$, while Foulds [54] found no correlation at all between foliar nutrient concentrations and $\mathrm{pH}$. However, the study by Foulds mostly covered neutral and basic soils, with only three sites with a $\mathrm{pH}$ below 6 , so it might be possible that the relationship between foliar $\mathrm{Ca}$ and $\mathrm{pH}$ becomes stronger at lower $\mathrm{pH}$ levels.

The correlations (Figure 2 and Table S4, Supplementary Materials) found among the nutrient concentrations in the different groups of species and the organic matter content and total nitrogen in the soil suggest that the good mineralization of organic matter, together with the high availability of nitrogen in the soil, increase nutrient uptake. The negative correlations between exchangeable Mg with foliar Ca (Table S4, Supplementary materials, Pearson coefficient $-0.411^{*}, p<0.05$ ) and between exchangeable Ca and foliar $\mathrm{Mg}$ (Table S4, Supplementary materials, Pearson coefficient $-0.510^{* *}, p<0.001$ ) suggest an antagonism where exchangeable $\mathrm{Mg}$ and $\mathrm{Ca}$ tend to inhibit the uptake of $\mathrm{Ca}$ and $\mathrm{Mg}$ in legumes and other families, respectively [58,59]. In other studies [44], strong correlations were found between foliar concentrations and soil exchangeable cations. However, in this work, exchangeable $\mathrm{K}$ was the only nutrient in the soil consistently correlated with the foliar content of the same nutrient in grasses, legumes (Table S4, Supplementary materials, Pearson coefficient $0.451^{*}, p<0.05$ ) and other families (Table S4, Supplementary materials, Pearson coefficient $0.472^{*}, p<0.05$ ). Exchangeable $\mathrm{Mg}$ was correlated with foliar Mg only in grasses (Table S4, Supplementary materials, Pearson coefficient $0.515^{* *}, p<0.001$ ).

The percentage of dry matter showed significant differences among the groups of species, appearing the highest percentages in the group of grasses (Table $6, p<0.001$ ). The same was true for the foliar content of $\mathrm{Mg}$ (Table 6, $p<0.05$ ), while the highest concentrations of foliar $\mathrm{P}$ were found in the group of other families (Table $6, p>0.05$ ).

\section{Conclusions}

Among the general properties of the representative soils in the 25 plots spread around five areas of hay meadows in Picos de Europa, the most remarkable results are the high contents of organic matter, the low $\mathrm{C} / \mathrm{N}$ and the high levels of soil available P. In fact, the soil $\mathrm{P}$ concentrations observed in this work are unlikely to limit plant growth. Therefore, continuous phosphate fertilization most likely will not produce an effect on plant development.

Concentrations of macronutrients in legumes and other families showed high levels in general, except in the case of foliar $\mathrm{K}$, which presented deficient levels. These low levels, together with the low soil $\mathrm{K}: \mathrm{Mg}$ ratio, represent low $\mathrm{K}$ availability for the plants. The nutrient metabolism in the family of grasses was affected by management practices. Foliar $\mathrm{P}$ and $\mathrm{K}$ were significantly higher in tractor mowed, fertilized meadows.

It was found that the combination of the different management techniques, i.e., fertilization and mowing, has a more important impact on the parameters studied than each of the techniques separately. Considering the high concentrations of soil available P and foliar $\mathrm{P}$, and on the contrary, the low concentrations of foliar K, it would be appropriate to revise fertilization management in the area.

Supplementary Materials: The following are available online at https:/ / www.mdpi.com/article/10.3 390/environments8050038/s1, Table S1: Approximate chronogram of the management in the meadows, Table S2: Correlation coefficients for the 18 variables (edaphic and foliar) and the first two principal components, Table S3: Mean values for variables affected by tractor and fertilization separately, Table S4: Pearson correlations among soil properties and foliar nutrients, Table S5: T-test comparing foliar nutrient concentrations with values given by Epstein, Excel Spreadsheet 1: Picos Europa Biomass Database, Excel Spreadsheet 2: Picos Europa Soils Database.

Author Contributions: Conceptualization, E.A.; Formal analysis, J.Á. and E.A.; Investigation, J.Á., E.A. and L.G.; Methodology, E.A. and L.G.; Project administration, E.A.; Resources, E.A.; Supervision, T.E.D.; Writing-original draft, J.Á.; Writing-review \& editing, E.A. and J.A.O. All authors have read and agreed to the published version of the manuscript. 
Funding: This research was funded by the European project Interreg SUDOE "SOS PRADERAS" SOE1/P5/E0376 and benefitted from FEDER funding 2014-2020.

Institutional Review Board Statement: Not applicable.

Informed Consent Statement: Not applicable.

Conflicts of Interest: The authors declare no conflict of interest. The funders had no role in the design of the study; in the collection, analyses, or interpretation of data; in the writing of the manuscript, or in the decision to publish the results.

\section{References}

1. Reiné Viñales, R. 6510 Prados de siega de montaña (Arrhenatherion). In Bases Ecológicas Preliminares Para la Conservación de los Tipos de Hábitat de Interés Comunitario en España; Ministerio de Medio Ambiente, y Medio Rural y Marino, Secretaría General Técnica, Centro de Publicaciones: Madrid, Spain, 2009; 60p.

2. Chocarro Gómez, C. 6520 Prados de siega de montaña (Triseto-Polygonion bistortae). In Bases Ecológicas Preliminares Para la Conservación de los Tipos de Hábitat de Interés Comunitario en España; Ministerio de Medio Ambiente, y Medio Rural y Marino, Secretaría General Técnica, Centro de publicaciones: Madrid, Spain, 2009; 48p.

3. Ferrer, C.; Barrantes, O.; Broca, A. La noción de biodiversidad en los ecosistemas pascícolas españoles. Pastos 2001, $31,129-184$.

4. Gibon, A.; Balent, G.; Alard, D.; Raich, J.M.; Ladet, S.; Mottet, A.; Julien, M.P. L'usage de l'espace par les exploitations d'élevage de montagne et la gestion de la biodiversité. Fourrages 2004, 178, 245-263.

5. Mora, A.; Rojo, F. Gestión activa de prados de siega en el Valle de Valdeón. Lopinga 2016, 1, 13-14.

6. Perrino, E.V.; Musarella, C.M.; Magazzini, P. Management of grazing Italian river buffalo to preserve habitats defined by Directive 92/43/EEC in a protected wetland area on the Mediterranean coast: Palude Frattarolo, Apulia, Italy. Euro. Mediterr. J. Environ. Integr. 2021, 13, 1682. [CrossRef]

7. Perrino, E.V.; Wagensommer, R.P. Crop wild relatives (CWR) priority in Italy: Distribution, ecology, in situ and ex situ conservation and expected actions. Sustainability 2021, 13, 1682. [CrossRef]

8. Barrantes, O.; Ferrer, C.; Reiné, R. Indicadores Para la Conservación de los Hábitat 6510 y 6520 (Prados de Siega de Montaña) en el Pirineo Aragonés (2010). Departamento de Agricultura y Economía Agraria. Universidad de Zaragoza, Spain. Available online: https://www.researchgate.net/profile/Ramon_Reine/publication/267808958_INDICADORES_ PARA_LA_CONSERVACION_DE_LOS_HABITAT_6510_Y_6520_PRADOS_DE_SIEGA_DE_MONTANA_EN_EL_PIRINEO_ ARAGONES_Autores/links/552385940cf29dcabb0f018e/INDICADORES-PARA-LA-CONSERVACION-DE-LOS-HABITAT6510-Y-6520-PRADOS-DE-SIEGA-DE-MONTANA-EN-EL-PIRINEO-ARAGONES-Autores.pdf (accessed on 10 July 2020).

9. Peiretti, P.G.; Tassone, S.; Vahdni, N.; Battelli, G.; Gai, F. Evaluation of the nutritive value and the fatty acid, phenol, tannin and terpenoid contents of nine pastures in an Alpine District during the summer season. Agriculture 2020, 10, 42. [CrossRef]

10. Dudek, T.; Wolański, P.; Rogut, K. The content of macro- and micro minerals in the sward of different types of semi natural meadows of temperate climate in SE Poland. Agronomie 2020, 10, 1-12.

11. Cernusca, A.; Tappeiner, U.; Bahn, M.; Bayfield, N.; Chemini, C.; Fillat, F.; Graber, W.; Rosset, M.; Siegwolf, R.; Tenhunen, J. Ecomont Ecological effects of land use changes on European terrestrial mountain ecosystems. Pirineos 1996, 147-148, 145-172. [CrossRef]

12. Adugna, A.; Abegaz, A. Effects of land use changes on the dynamics of selected soil properties in northeast Wellega, Ethiopia. Soil 2016, 2, 63-70. [CrossRef]

13. Emiru, N.; Gebredikan, H. Effects of land use changes and soil depth on soil organic matter, total nitrogen and available phosphorous contents of soils in Senbat Watershed, Western Ethiopia. J. Agric. Biol. Sci. 2013, 8, 206-212.

14. Mayel, S.; Jarrah, M.; Kuka, K. How does grassland management affect physical and biochemical properties of temperate grassland soils? A review study. Grass Forage Sci. 2021, 1-30. [CrossRef]

15. Messiga, A.J.; Ziadi, N.; Bélanger, C.; Morel, C. Soil nutrients and other major properties in grassland fertilized with nitrogen and phosphorous. Soil Sci. Soc. Am. J. 2013, 77, 643-652. [CrossRef]

16. Vargová, V.; Kanianska, R.; Kizeková, M.; Šiška, B.; Kováčiková, Z.; Michalec, M. Changes and interactions between grassland ecosystem soil and plant properties under long-term mineral fertilization. Agronomy 2020, 10, 375. [CrossRef]

17. Hrevušová, Z.; Hejcman, M.; Hakl, J.; Mrkvička, J. Soil chemical properties, plant species composition, herbage quality, production and nutrient uptake of an alluvial meadows after 45 years of N, P and K application. Grass Forage Sci. 2014, 70, 205-218. [CrossRef]

18. Ulén, B.; Bechmann, M.; Fölster, J.; Jarvie, H.P.; Tunney, H. Agriculture as a phosphorus source for eutrophication in the north-west European countries, Norway, Sweden, United Kingdom and Ireland: A review. Soil Use Manag. 2007, 23, 5-15. [CrossRef]

19. Smits, N.A.C.; Willems, J.H.; Bobbink, R. Long-term after-effects of fertilisation on the restoration of calcareous grasslands. Appl. Veg. Sci. 2008, 11, 279-286. [CrossRef]

20. Rivas-Martínez, S.; Bandullo, J.M.; Allue, J.L.; Montero, J.L.; González, J.L. Memoria del Mapa de Series de Vegetación de España; Ediciones ICONA-MAPA: Madrid, Spain, 1987; ISBN 84-85496-25-6. 
21. Aguiar, C.; Castro, J.P.; Bastos, P.; Monteiro-Henriques, T.; Cambecedes, J.; García Manteca, P.; de la Fuente, G.L.; Afif, E.; Mora, A.; Guzmán, D.; et al. GT1. Diagnóstico de la situación de prados de siega en el territorio SUDOE. In Report Coordinated by Carlos Aguiar within the Interreg SUDOE Project "SOS PRADERAS"; Díaz, T.E., Ed.; University of Oviedo: Oviedo, Spain, 2018.

22. Soil Survey Staff. In Claves Para la Taxonomía de Suelos; Servicio de Conservación de los Recursos Naturales; Departamento de Agricultura de los Estados Unidos: Washington, DC, USA, 2010.

23. García, P.; de la Fuente, G.L.; González, V. Diagnóstico de la situación de prados de siega en el suroeste europeo: Análisis diacrónico en el Parque Nacional de los Picos de Europa. Nat. Cantab. 2018, 6, 1-21.

24. De la Fuente, G.L.; García, P. Muestreo socioeconómico sobre el manejo de prados de siega en el P.N.P.E. In Unpublished Report Developed by INDUROT-University of Oviedo within the Interreg SUDOE Project "SOS PRADERAS"; Díaz, T.E., Ed.; INDUROTUniversity of Oviedo: Oviedo, Spain, 2017; Unpublished work.

25. Thomas, G.W. Soil pH and soil acidity. Methods Soil Anal. Part 3 Chem. Methods 1996, 5, 475-490.

26. Schulte, E.E.; Hopkins, B.G. Estimation of organic matter by weight loss-on-ignition. In Soil Organic Matter: Analysis and Interpretation Guide; Soil Science Society of America: Madison, WI, USA, 1996; pp. 21-31.

27. Klute, A. Nitrogen-total. In Methods of Soil Analyses, Part 1, 2nd ed.; Klute, A., Ed.; American Society of Agronomy: Madison, WI, USA, 1996; pp. 595-624.

28. Mehlich, A. Mehlich 3 soil test extractant: A modification of Mehlich 2 extractant. Soil Sci. Plant. Anal. 1985, 15, 1409-1416. [CrossRef]

29. Pansu, M.; Gautheyrou, J. Handbook of Soil Analysis: Mineralogical, Organic and Inorganic Methods; Springer Science \& Business Media: Berlin, Germany; Springer-Verlag Berlin Heidelberg: Berlin, Germany, 2007; pp. 667-684.

30. Taboada, M.A.; Álvarez, C.R. Fertilidad Física de los Suelos, 2nd ed.; Agronomy Faculty, University of Buenos Aires: Buenos Aires, Argentina, 2008; ISBN 978-850-29-1074-1.

31. Shanina, T.M.; Geiman, N.E.; Mikhallovakaya, V.S. Quantitative analysis of heterogenic compounds: Spectrophotometric micro determination of boron. Fresenius Z. Anal. Chem. 1967, 22, 663-667.

32. Gee, G.W.; Bauder, J.W. Particle size analysis. In Methods of Soil Analysis; Klute, A., Ed.; American Society of Agronomy: Madison, WI, USA, 1996; pp. 383-411.

33. Smith, T.M.; Smith, R.L. Elements of Ecology, 7th ed.; Person International Edition; Pearson Benjamin Cummings: San Francisco, CA, USA, 2009; ISBN 978-0-321-56147-3.

34. Jones, J.B.; Wolf, B.; Mill, H.A. Plant Analysis Handbook: A Practical Sampling Preparation; Analysis and Interpretation Guide; Micro-Macro Publishing: Athens, GA, USA, 1991; ISBN 978-1878148001.

35. Field, A. Discovering Statistics Using IBM SPSS Statistics; Sage: London, UK, 2013.

36. Trueba, C.; Millán, R.; Schmid, T.; Roquero, C.; Magister, M. Base de datos de propiedades edafológicas de los suelos españoles. Volume II: Asturias, Cantabria y País Vasco. Inf. Técnicos 1998.

37. Afif, E.; Oliveira, J.A. Relación propiedades edáficas-estado nutricional de pastos en varios puertos de Asturias. In Actas XLVII Reunión Científica de la SEEP, Clave en la Gestión de los Territorios: Integrando Disciplinas; Junta de Andalucía: Córdoba, Spain, 2008; pp. 281-286.

38. Nicolardot, B.; Recous, S.; Mary, B. Simulations of C and N mineralisation during crop residue decomposition: A simple dynamic model based on the C:N ratio of the residues. Plant Soil 2001, 228, 82-103. [CrossRef]

39. García, F.O. Fertilidad de Suelos y Fertilización de Cultivos; Ediciones INTA: Buenos Aires, Argentina, 2014; ISBN 978-987-521-565-8.

40. Tomasic, M.; Zgorelec, Z.; Jurisic, A.; Kisic, I. Cation exchange capacity of dominant soil types in the Republic of Croatia. J. Cent. Eur. Agric. 2013, 14, 84-89. [CrossRef]

41. Affif, E.; Líbano, E.C.; Varela, J.J.G.; Obregón, A.C. Relación Entre las Propiedades del Suelo, Incremento en Volumen Anual y Estado Nutricional de Eucalyptus Globulus y Pinus Radiata D; DON en Asturias (Noroeste de España); University of Oviedo: Oviedo, Spain, 2008.

42. Bergaya, F.; Vayer, M. CEC of clays: Measurement by adsorption of a copper ethylenediamine complex. Appl. Clay Sci. 1997, 12, 275-280. [CrossRef]

43. Woodruff, W.F.; Revil, A. CEC-normalized clay-water sorption isotherm. Water Resour. Res. 2011, 47, 11. [CrossRef]

44. Holford, I.C.R. Soil phosphorus: Its measurements and its uptake by plants. Soil Res. 1997, 35, 227-240. [CrossRef]

45. Castellanos, J.Z.; Uvalle-Bueno, J.X.; Aguilar-Santelises, A. Manual de Interpretación de Análisis de Suelos y Aguas Agrícolas, Plantas y ECP; Instituto de Capacitación Para la Productividad Agrícola: Chapingo, Mexico, 2000; ISBN 1097729888.

46. Pocknee, S.; Sumner, M.E. Carbon and nitrogen contents of organic matter determine its soil liming potential. Soil Sci. Soc. Am. J. 1997, 61, 86-92. [CrossRef]

47. Recena, R.; Díaz, I.; del Campillo, M.C.; Torrent, J.; Delgado, A. Calculation of threshold Olsen P for fertilizer response from soil properties. Agron. Sustain. Dev. 2016, 36, 1-8. [CrossRef]

48. Afif, E.; Oliveira, J.A. Pérdida de disponibilidad y niveles críticos de fósforo Mehlich 3 en suelos no calcáreos de Asturias. Pastos 2005, 35, 163-178.

49. Bai, Z.; Li, H.; Yang, X.; Zhou, B.; Shi, X.; Wang, B.; Li, D.; Shen, J.; Chen, Q.; Qin, W.; et al. The critical soil P levels for crop yield, soil fertility and environmental safety in different soil types. Plant Soil 2013, 372, 27-37. [CrossRef]

50. Jagadamma, S.; Lal, R.; Hoeft, R.G.; Nafziger, E.D.; Adee, E.A. Nitrogen fertilization and cropping system impacts on soil properties and their relationship to crop yield in the Central Corn Belt, USA. Soil Till. Res. 2008, 98, 120-129. [CrossRef] 
51. Vera, A.L.A. El boro como nutriente esencial. Horticultura 2001, 155, 36-47.

52. Epstein, E. Mineral Nutrition of Plants; Principles and Perspective; John Wiley \& Sons: New York, NY, USA, 1972.

53. Leigh, R.A.; Wyn Jones, R.G. A hypothesis relating critical potassium concentrations for growth to the distribution and functions of this ion in the plant cell. New Phytol. 1984, 97, 1-13. [CrossRef]

54. Foulds, W. Nutrient concentrations of foliage and soil in South-Western Australia. New Phytol. 1993, 125, 529-546. [CrossRef] [PubMed]

55. Thompson, K.; Parkinson, J.A.; Band, S.R.; Spencer, R.E. A comparative leaf study of leaf nutrient concentrations in a regional herbaceous flora. New Phytol. 1997, 136, 679-689. [CrossRef] [PubMed]

56. McNaught, K.J. Potassium deficiency in pastures: I. Potassium content of legumes and grasses. N. Z. J. Agric. Res. 1958, 1, $148-181$. [CrossRef]

57. Rodríguez, M.; García, R.; Andrés, S.; Calleja, A. Cuarenta años de fertilización en prados de la montaña de León. III Influencia sobre la composición química y valor nutritivo. Pastos 2006, 26, 45-79.

58. Mesa, A.R.; Figueroa, M. Status nutritivo de suelos en áreas ganaderas. I. Suelo Mocarrero. Pastos Forrajes 1979, 2 , $255-264$.

59. Molina, E. Análisis de Suelos y su Interpretación (2007). Centro de Investigaciones Agronómicas, Universidad de Costa Rica. Available online: http://www.infoagro.go.cr/Inforegiones/RegionCentralOriental/Documents/Suelos/SUELOSAMINOGROWanalisiseinterpretacion.pdf (accessed on 3 July 2020). 